Setiawatie et al., Afr., J. Infect. Dis. (2018) 12(S): 95-103

https://doi.org/10.2101/Ajid.v12i1S.14

\title{
COMPARISON OF ANTI BACTERIAL EFFICACY OF PHOTODYNAMIC THERAPY AND DOXYCYCLINE ON AGGREGATIBACTER ACTINOMYCETEMCOMITANS
}

\author{
Ernie Maduratna Setiawatie ${ }^{1}$, Vina Puji Lestari ${ }^{2}$, Suryani Dyah Astuti ${ }^{2 *}$ \\ ${ }^{1}$ Department of Periodontics, Faculty of Dentistry, Airlangga University, Indonesia; ${ }^{2}$ Department of Physics, \\ Faculty of Science and Technology, Airlangga University, Indonesia
}

*Corresponding Author Email: suryanidyah@gmail.com

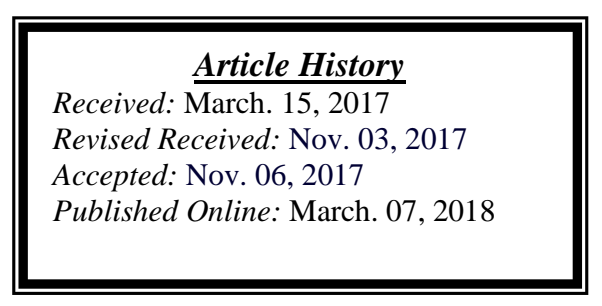

\begin{abstract}
Background: Aggregatibacter actinomycetemcomitans (A.actinomycetemcomitans) is an anaerobic bacterium has been frequently associated with aggressive periodontitis. Photodynamic therapy (PDT) is a medical treatment to prevent infection progression that utilizes light to activate a photosensitizing agent. Doxycycline is an antibacterial having photosensitivity. This study aimed to evaluate potential doxycycline as an antibacterial and photosensitizer combine PDT against A.actinomycetemcomitans bacteria.

Material and methods: Samples were distributed to 4 groups as follow: (1) Groups A treated with a diode laser, (2) Group B treated with doxycycline $0,1 \%$ and laser, (3) Group C treated only with Doxycycline $0.1 \%$, and (4) Group D no exposure doxycycline/laser. Data were analyzed by one-way ANOVA and Tukey's HSD test at 5\% significance level.

Results: In this study, doxycycline $0.1 \%$ has the effect of reducing the bacterial viability of $(59.60 \pm 3.26 \%)$. Whereas laser exposure $120 \mathrm{~s}$ combined with doxycycline produce the effect of bacterial viability reduction $(88.50 \pm 2.83 \%)$ is not significantly different from the effect of laser $120 \mathrm{~s}$ exposure $(88.79 \pm 2.60 \%)$. In clinical treatment, the application of laser exposure is generally at the duration of the exposure time of $30 \mathrm{~s}$. The results of this study indicate that the duration of laser exposure $30 \mathrm{~s}$ shows a reduction in bacterial viability $(44.91 \pm 1.69 \%)$ equal to the laser and with a combination of doxycycline and laser exposure $(70.70 \pm 2.43 \%)$. So at low doses of laser exposure, doxycycline $0.1 \%$ combined with the laser results in the greatest reduction in bacterial viability, significantly different from laser exposure alone.

Conclusion: at low doses of laser exposure (30s with energy $\left.3.68 \mathrm{~J} / \mathrm{cm}^{2}\right)$, doxycycline $0.1 \%$ combined with the laser results in the greatest reduction in bacterial viability, significantly different with laser exposure alone.
\end{abstract}

Keywords: Photodynamic therapy, doxycycline, Aggregatibacter actinomycetemcomitans

\section{Introduction}

Aggressive periodontitis is an infectious disease its association rapidly progressing. These patients require treatment to prevent further progression of the disease and tissue damage. Aggregatibacter actinomycetemcomitans (A.actinomycetemcomitans) has an important key to the development of aggressive periodontitis (Lai et al., 2013). A. actinomycetemcomitanshas several virulence factors to invade epithelial cells, resisting phagocytosis, and produce leukotoxin and cytolethal descending toxin (Curtis et al., 2011)

Scaling and root planning has been regarded as a standard treatment for periodontitis. However, the treatments cannot produce clinical improvement, especially in cases of advanced disease and periodontal pockets inside, due to no considerable changes in subgingival microbial composition and they do not have to target specific bacterial species. Actinomyces species was the first bacteria that colonized after scaling and root planning procedure, then continuing by higher numbers and a larger proportion of pathogenic bacteria from red and orange group bacteria by slower recolonization (Brayton et al., 2002). Mechanical debridement leaves a large number of pathogenic microorganisms in relatively inaccessible areas, and cause a disturbance on subgingival flora.

Treatment of periodontitis using local antibiotics was intended as an adjunct to non-surgical treatment and to kill pathogenic bacteria from subgingival and extra crevicular niches. Various methods used as antimicrobial agents include rinsing, irrigation, systemic administration, and local applications using the sustained and controlled delivery 
(Sgolastra et al., 2013). Systemic administration allows antimicrobial agents to reach all periodontal and oral sites. However, the drug effect in the periodontal pocket is relatively low and raises the risk of side effects on non-oral sites of the body. Drugs may also be used as mouth rinses and for subgingival irrigation, but the depth of drugs penetration to the periodontal pocket is limited. Oral irrigation cannot facilitate drug penetration into the deepest area of the pocket. Self-irrigation may be limited by low patient compliance. Therefore, many studies have assessed the effect of local antiseptics and antibiotics only as adjunctive therapy for a periodontal case.

Local antimicrobial therapy is generally used during the maintenance phase to treat any remaining bacteria that isolated by the active pocket. Systemic antibiotics produce adverse drug reactions, uncontrolled patient compliance, and low drug concentrations in the subgingival sites. Local delivery is controlled from within the periodontal pocket.Single administration of antibacterial agent in small amount can maintain therapeutic concentrations in the gingival sulcus fluid for a longer period than other modes of delivery (de Melo et al., 2013). Doxycycline is a derivate of tetracycline, which is effective against A.actinomycetemcomitans. The A.actinomycetemcomitans has resistance $8.9 \%$ to doxycycline. Aggressive periodontitis is a progressive disorder of periodontal tissues, it is characterized by the rapid loss of connective tissue attachment and alveolar bone crushing on more than one permanent tooth. A.actinomycetemcomitans bacteria were the most dominant microorganisms found in patients with subgingival aggressive periodontitis bacteria and it is prevalent in Indonesia (Setiawatie et al., 2016).

Administration of local doxycycline produces anti-inflammation effects by inhibition of nuclear factor kappa $\beta$ in the oral epithelium. Doxycycline can kill bacteria A.actinomycetemcomitans in the epithelial cells, and intracellular accumulation of doxycycline may combat invasive bacteria from the gingival epithelium (Moslemi et al., 2012). However, the disadvantage of doxycycline administration is photosensitivity effect on UV-A (Peacock et al., 2000). New treatments of periodontal disease are needed to prevent the progress of the infection. Doxycycline having photosensitivity effect may have a probability as a photosensitizer. Evaluation of the effective therapy was carried out as the advent of new technologies. Laser therapy, able to call by photodynamic therapy, is increasingly popular treatment, which offers an alternative and selective efficacy. Light therapy is based on the observation that periodontopathic bacteria capable of synthesizing chromophores, such as porphyrin. An in vitro study showed that blue light activation of the porphyrin caused structural damage in A.actinomycetemcomitans membranes and cause cell death. Illumination of the blue light laser $(407-420 \mathrm{~nm})$ was able to decrease bacterial growth after 24 hours (Séguier et al., 2010; Choi et al., 2012). This research aimed to evaluate potential doxycycline on A.actinomycetemcomitans (ATCC 43718, USA) bacteria as photosensitizer combine PDT with the blue laser diode.

\section{Materials and Methods \\ Bacterial Strain and Culture Condition}

A strain bacteria was used Aggregatibacter actinomycetemcomitans (ATCC 43718, USA) which grown on Tryptic Soy Agar (TSA) solution (Oxoid CM0131, UK). Isolate bacteria were taken 1 inoculating loop and placed on Tryptic Soy Broth (TSB) solution (Merck Millipore, Germany). Culture was placed on anaerobic jar and saved on incubator $\mathrm{CO}_{2} 37^{\circ} \mathrm{C}$ until formed suspense bacteria $\sim 10^{10} \mathrm{CFU} / \mathrm{ml}$ or $0.5 \mathrm{McF}$ arland Standard.

To determine the effect of the antibiotic on these A. actinomycetemcomitans, doxycycline dissolved in sterile water, or sterile water as a control, was injected into each tube and incubated for $30 \mathrm{~min}$. A. actinomycetemcomitans was incubated in Petri dishes. was incubated in Tryptic Soy Agar (TSA) supplemented with $0.5 \%$ yeast extract in the microaerophilic atmosphere at $35^{\circ} \mathrm{C}$ for $48 \mathrm{~h}$ to obtain strains at exponential growth phase. A. actinomycetemcomitans colony forming units (CFU) were inoculated into Tryptic Soy Broth (TSB) supplemented with 0.5\% yeast extract, respectively. Then, $1 \mathrm{~mL}$ of CFU of each strain was aspirated with a disposable pipette from the dishes and the volume was dispersed in a sterile $10 \mathrm{~mL}$ tube, which was agitated in a tube agitator to spread bacterial strains. This tube was subjected to concentration analysis in a $640 \mathrm{~nm}$ spectrophotometer to reach a value between $0.08-0.1 \mathrm{~nm}$ corresponding to the final concentration of $1.5 \times 108 \mathrm{UFC} / \mathrm{mL}$. Suspense bacteria was taken $0.1 \mathrm{ml}$ after the last dilution and placed on a petri dish and pour TSA solution. Petri dishes were placed on an anaerobic jar and saved on incubator $\mathrm{CO}_{2} 37^{\circ} \mathrm{C}$ for 24 hours.

\section{Materials}

Doxycycline used in this research was water soluble doxycycline hydrochloride (Doxycycline hyclate; SigmaAldrich). Doxycycline $0.1 \%$ (w/v) was freshly prepared for each experiment. The absorption spectrum of doxycycline was characterized by UV-Vis spectrophotometer 1800 Shimadzu.

\section{Apparatus Chamber for Illumination}

Laser irradiations were carried out using diode lasers. Wavelength and power output will be shown on this result. The experiment design used 6 times exposure variations, 10s, 30s, 50s, 70s, 90s, and 120s.

\section{Treatments}

Samples were distributed to 4 groups as follow: (1) Groups A treated with a diode laser, (2) Group B treated with doxycycline $0.1 \%$ and laser, (3) Group C treated only with Doxycycline $0.1 \%$, and (4) Group D no exposure 
doxycycline/laser. Samples were bacterial growth suspense and taken $1 \mathrm{ml}$ on eppendorf. Each group of the experiment was repeated at least 4 times. The number of colony-forming units per milliliter $(\mathrm{CFU} / \mathrm{ml})$ was then determined. The results were analyzed by analysis of variance (ANOVA) test. A value of $p \leq 0.05$ was considered as a statistically significant difference. Percentage of decrease in the number of bacterial colonies growth defined as:

$$
\left|\frac{(\Sigma \text { sample colony }-\Sigma \text { control colony })}{\Sigma \text { control colony }}\right| \times 100 \%
$$

\section{Results}

This study used antibiotics doxycycline, which is generally indicated for people with the infection. However, in this study doxycycline is indicated as a photosensitizer diode laser as a bacterial inactivation agent. Therefore, doxycycline absorbance test using UV-Vis 1800 Series spectrophotometer to know the absorbance spectrum and the length of the wave match between doxycycline with diode laser wavelength were carried out. This absorption test is needed to determine the radiation that microorganisms receive through the absorption results (quantum yield). In this study, the laser used has a wavelength of $409 \mathrm{~nm}$, then at that wavelength absorbance value is obtained which shows the absorbance relationship to the wavelength graph presented in Figure 1.

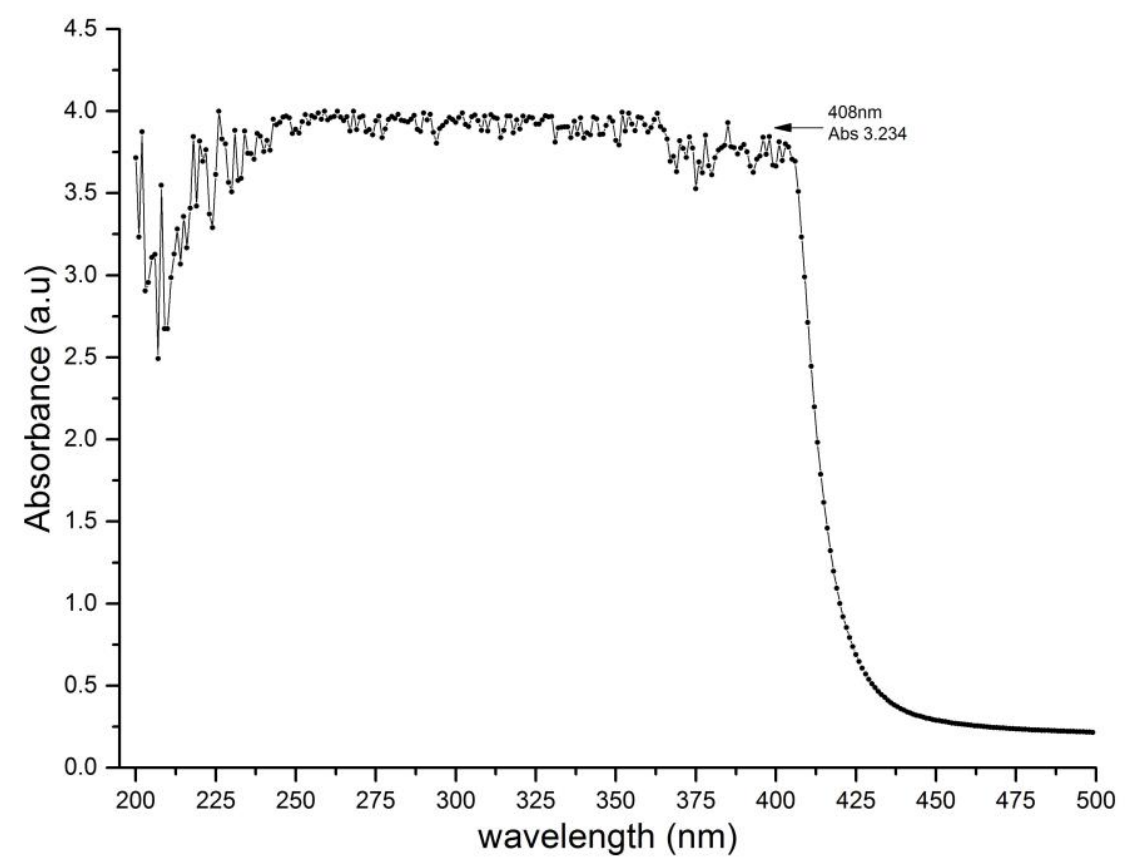

Figure 1: The absorption spectrum of doxycycline as in wavelength of $200-500 \mathrm{~nm}$

Figure 1 showed the absorption spectrum of doxycycline. Based on the test results, it can be calculated the ratio of absorbance and transmission to determine the percentage of absorption (Quantum Yield) doxycycline, ie through the equation:

$$
\begin{aligned}
& \text { Abs }=-\log T=\log \frac{1}{T} \\
& T=10^{-A b s} \\
& T=10^{-2.990} \\
& T=0.00102 \\
& \begin{aligned}
\% \text { Absorption }(Q) & =(1-T) \times 100 \% \\
& =(1-0.00102) \times 100 \%=99.99 \%
\end{aligned}
\end{aligned}
$$

From the calculation, the results obtained that the percentage of doxycycline uptake at $409 \mathrm{~nm}$ wavelength is 99.98\% which means that the greater the absorbance value of a sample the better the nature of the sample in the absorption. After the percentage of absorption was known, radiation calculations can be performed in Table 1, through the equation:

$R=\frac{P}{A} \times t \times Q$ 
With $\mathrm{R}$ being radiation, $\mathrm{P}$ is potency to the radiation distance, A laser beam area, $\mathrm{t}$ the time variation used during irradiation, and $\mathrm{Q}$ is the quantum yield (\% absorption).

Table 1: Irradiation data with time variation

\begin{tabular}{|c|c|c|c|c|c|}
\hline $\begin{array}{l}\text { Laser Power } \\
\text { (W) }\end{array}$ & Area $\left(\mathrm{cm}^{2}\right)$ & $\begin{array}{c}\text { Wave length } \\
(\mathrm{nm})\end{array}$ & $\begin{array}{c}\text { Doxycycline } \\
\text { Uptake }\end{array}$ & $\begin{array}{l}\text { Time } \\
\text { (s) }\end{array}$ & $\begin{array}{c}\text { Radiation } \\
\left(\mathrm{J} / \mathrm{cm}^{2}\right)\end{array}$ \\
\hline \multirow{6}{*}{0.049502} & \multirow{6}{*}{0.403} & \multirow{6}{*}{409} & \multirow{6}{*}{$\begin{array}{l}0.999898 \\
(99,98 \%)\end{array}$} & 10 & 1.228 \\
\hline & & & & 30 & 3.684 \\
\hline & & & & 50 & 6.140 \\
\hline & & & & 70 & 8.597 \\
\hline & & & & 90 & 11.053 \\
\hline & & & & 120 & 14.737 \\
\hline
\end{tabular}

Prior to laser diode irradiation of A.actinomycetemcomitans, it is necessary to establish Mc Farl and standard and perform a dilution standard of A.actinomycetemcomitans bacteria first. The results of standard Mc Farl and are shown in Table 2.

Table 2: Data of Mc Farl and standard establishment

\begin{tabular}{|c|c|c|c|c|c|c|c|c|}
\hline \multirow{2}{*}{$\begin{array}{c}\text { OD } \\
595 \mathrm{~nm}\end{array}$} & \multirow{2}{*}{ Dilution to- } & \multicolumn{4}{|c|}{ Sample } & \multirow{2}{*}{ Average } & \multirow{2}{*}{ CFU/ml } & \multirow{2}{*}{$\begin{array}{c}\log \\
\text { CFU/ml }\end{array}$} \\
\hline & & 1 & 2 & 3 & 4 & & & \\
\hline 0.44 & 5 & 451 & 578 & 198 & 390 & 404.25 & $8.09 \times 10^{-7}$ & 7.908 \\
\hline 0.54 & 6 & 372 & 424 & 343 & 354 & 373.25 & $7.47 \times 10^{-8}$ & 8.873 \\
\hline 0.59 & 7 & 369 & 190 & 321 & 272 & 288 & $5.76 \times 10^{-9}$ & 9.760 \\
\hline 0.65 & 8 & 128 & 178 & 130 & 124 & 140 & $2.80 \times 10^{-10}$ & 10.447 \\
\hline
\end{tabular}

Based on Table 2, a Mc Farland standard chart is presented in Figure 3. The graph serves to measure bacterial density optically through ELISA Reader and compare it to the number of bacterial colonies in CFU / $\mathrm{ml} \mathrm{Log}$

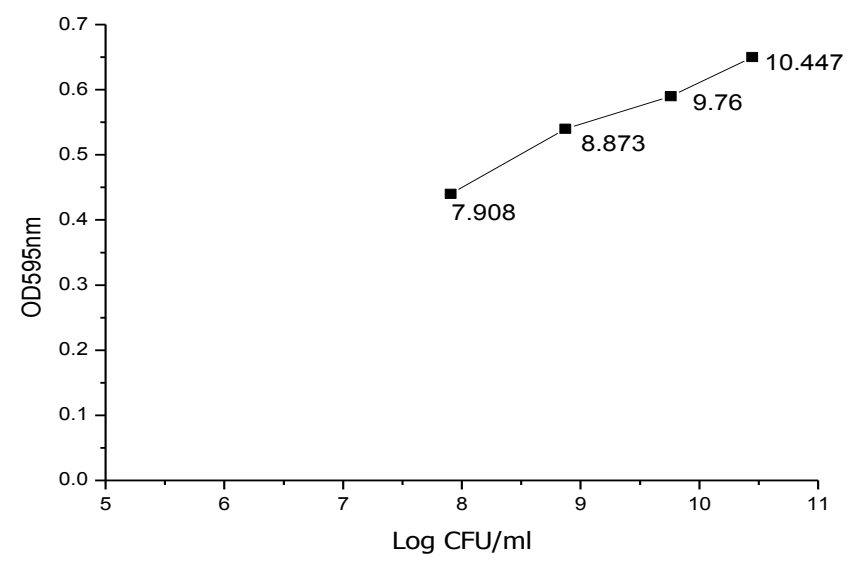

Figure 2: Mc Farland's standard graph

In Table 2 it is known that the average number of colonies of A.actinoycetemcomitans bacteria with 30-300 colonies requirement is found in the dilution factor of $10^{-7}$ ( 7 th dilution) with an OD value of 0.5 . After the Mc Farland standard was known, furthermore the dilution standard of the A.actinoycetemcomitans bacteria established presented in Table 3. This dilution standard aims to determine on which dilution is reached the bacterial viability colonies ranges from 30-300 so that the results can be used as a comparison reference to the control group and the treatment group when irradiated using a diode laser. 
Table 3: Results of Dilution Standard of A.actinomycetemcomitans Bacteria

\begin{tabular}{|c|c|c|c|c|c|c|c|}
\hline \multirow{2}{*}{ Dilution to- } & \multicolumn{4}{|c|}{ Sample } & \multirow{2}{*}{ Average } & \multirow{2}{*}{ CFU/ml } & \multirow{2}{*}{$\begin{array}{c}\text { Log } \\
\text { CFU/ml }\end{array}$} \\
\hline & 1 & 2 & 3 & 4 & & & \\
\hline $10^{-5}$ & 445 & 329 & 418 & 401 & 398.25 & $7.97 \times 10^{7}$ & 7.90 \\
\hline $10^{-6}$ & 335 & 395 & 431 & 399 & 390.00 & $7.80 \times 10^{8}$ & 8.89 \\
\hline $10^{-7}$ & 267 & 294 & 271 & 292 & 281.00 & $5.62 \times 10^{9}$ & 9.75 \\
\hline $10^{-8}$ & 148 & 118 & 101 & 132 & 124.75 & $2.50 \times 10^{10}$ & 10.39 \\
\hline $10^{-9}$ & 81 & 83 & 97 & 68 & 82.25 & $1.65 \times 10^{11}$ & 11.21 \\
\hline $10^{-1^{0}}$ & 68 & 56 & 47 & 53 & 56.00 & $1.12 \times 10^{12}$ & 12.04 \\
\hline
\end{tabular}

In Table 3 it is known that the average number of bacterial colonies in the $7^{\text {th }}$ dilution is 281 colonies, a large number of bacteria is included in the good range of dilution because it is still within the range of 30-300 colonies so that the results obtained the standard dilution of A.actinomycetemcomitans is at the 7th dilution. After performing the Mc Farland standard and obtaining the standard bacterial dilution, the diode laser irradiation is carried out on A.actinomycetemcomitans.

Table 4 shows the viability of bacterial colonies in various treatments. Figure 3 shows the viability of bacterial colonies in various time of diode laser irradiation, with and without doxycycline. Irradiation of diode laser within $120 \pm 0,005$ s decreases the number of A.actinomycetemcomitans by $86.33 \pm 3.01 \%$. The viability of bacteria decreases by $69.80 \pm 2.91 \%$ with the administration of doxycycline. Combination of diode laser irradiation with doxycycline cause the highest decrease in bacterial viability $(88.93 \pm 2.50 \%)$.

Table 4: The percentage reduction of bacterial viability in various treatments

\begin{tabular}{|c|c|c|c|c|c|c|}
\hline $\begin{array}{l}\text { Treatments } \\
\text { group }\end{array}$ & $\begin{array}{c}\text { Time ex- } \\
\text { posure (s) }\end{array}$ & $\begin{array}{l}\text { Laser intensi- } \\
\text { ty }\left(\mathrm{J} / \mathrm{cm}^{2}\right)\end{array}$ & $\begin{array}{c}\text { Number of } \\
\text { Colonies }\end{array}$ & CFU/ml & $\begin{array}{c}\text { Log } \\
\text { CFU/ml }\end{array}$ & $\begin{array}{c}\% \text { reduction of } \\
\text { viability }\end{array}$ \\
\hline \multirow{7}{*}{ Control } & 0 & - & 288 & $5.32 \mathrm{E}+09$ & 9.726 & 0 \\
\hline & 10 & - & 265.75 & $5.76 \mathrm{E}+09$ & 9.760 & 0 \\
\hline & 30 & - & 269.25 & $5.39 \mathrm{E}+09$ & 9.731 & 0 \\
\hline & 50 & - & 276.5 & $5.53 \mathrm{E}+09$ & 9.743 & 0 \\
\hline & 70 & - & 301.25 & $6.03 E+09$ & 9.780 & 0 \\
\hline & 90 & - & 303 & $6.06 \mathrm{E}+09$ & 9.782 & 0 \\
\hline & 120 & - & 259.75 & $5.20 \mathrm{E}+09$ & 9.716 & 0 \\
\hline \multirow{7}{*}{ Laser } & 0 & 0.000 & 275.5 & $5.51 \mathrm{E}+09$ & 9.741 & 4.36 \\
\hline & 10 & 1.228 & 157.75 & $3.16 \mathrm{E}+09$ & 9.499 & 42.74 \\
\hline & 30 & 3.685 & 151.75 & $3.04 \mathrm{E}+09$ & 9.482 & 44.91 \\
\hline & 50 & 6.141 & 148.5 & $2.97 \mathrm{E}+09$ & 9.473 & 46.28 \\
\hline & 70 & 8.598 & 142.25 & $2.85 \mathrm{E}+09$ & 9.454 & 48.37 \\
\hline & 90 & 11.055 & 84.5 & $1.69 \mathrm{E}+09$ & 9.228 & 69.33 \\
\hline & 120 & 14.740 & 35.5 & $7.10 \mathrm{E}+08$ & 8.851 & 88.50 \\
\hline \multirow{7}{*}{ Doxy } & 0 & - & 224.25 & $4.49 \mathrm{E}+09$ & 9.652 & 15.62 \\
\hline & 10 & - & 123.5 & $2.47 \mathrm{E}+09$ & 9.393 & 44.92 \\
\hline & 30 & - & 114.25 & $2.29 \mathrm{E}+09$ & 9.359 & 49.05 \\
\hline & 50 & - & 110.75 & $2.22 \mathrm{E}+09$ & 9.345 & 50.61 \\
\hline & 70 & - & 96.25 & $1.93 \mathrm{E}+09$ & 9.284 & 57.08 \\
\hline & 90 & - & 91.5 & $1.83 \mathrm{E}+09$ & 9.262 & 59.19 \\
\hline & 120 & - & 90.5 & $1.81 \mathrm{E}+09$ & 9.258 & 59.64 \\
\hline \multirow{3}{*}{ Laser + Doxy } & 0 & 0.000 & 250 & $5.00 \mathrm{E}+09$ & 9.699 & 5.93 \\
\hline & 10 & 1.228 & 104.25 & $2.09 \mathrm{E}+09$ & 9.319 & 58.30 \\
\hline & 30 & 3.684 & 73.25 & $1.47 \mathrm{E}+09$ & 9.166 & 70.70 \\
\hline
\end{tabular}




\begin{tabular}{rc|cccc}
50 & 6.140 & 57 & $1.14 \mathrm{E}+09$ & 9.057 & 77.20 \\
70 & 8.597 & 56 & $1.12 \mathrm{E}+09$ & 9.049 & 77.60 \\
90 & 11.053 & 53.75 & $1.08 \mathrm{E}+09$ & 9.031 & 78.50 \\
\hline 120 & 14.737 & 28.75 & $5.75 \mathrm{E}+08$ & 8.760 & 88.79 \\
\hline
\end{tabular}

The irradiation was done by culturing the isolates of A.actinomycetemcomitans bacteria which were then incubated for 24 hours. For the treatment group, a $0.1 \%$ concentration of doxycycline antibiotic was added. Then the irradiation treatment using diode laser is started. At this stage, the sample consisted of 4 treatment groups. Each group consists of six time variations ie $10 \mathrm{~s}, 30 \mathrm{~s}, 50 \mathrm{~s}, 70 \mathrm{~s}, 90 \mathrm{~s}$, and $120 \mathrm{~s}$. The number of bacterial colonies obtained from diode laser transmission in A.actinomycetemcomitans bacteria presented in Figure 3.

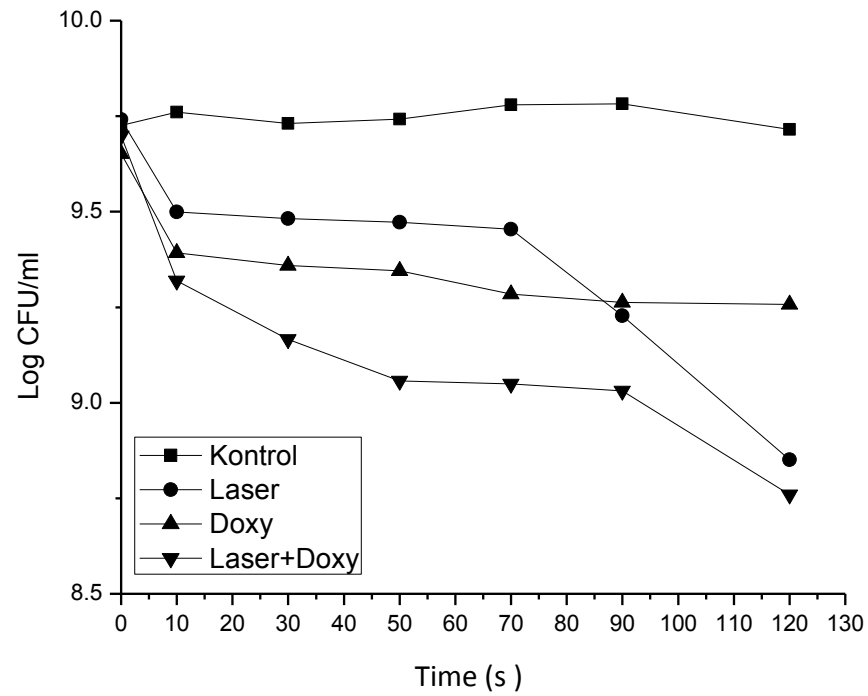

Figure 3: Bacterial viability in varying treatment of laser and doxycycline $0.1 \%$

Statistical analysis results in the significant difference between treatments $(\mathrm{p}<0.05)$. Group A (laser treatment) has different irradiation in $120 \mathrm{~s}$ and has most of decreased. It has a similar pattern to Group B (combine laser and doxycycline). The statistically significant decrease of CFU was found on the diode laser treatment group (Group A and Group B) $(\mathrm{p}<0.05)$ compared to the control group. Tukey post hoc test results show that exposure of diode laser with the irradiation time of $120 \pm 0.005$ s produced the highest decrease in the number of A.actinomycetemcomitans $88.79 \%$. It is not significantly different with laser treatment at $120 \mathrm{~s}$. Table 5 shows the results of ANOVA factorial test of the treatments.

Table 5: The results of ANOVA factorial test and post hoc of the treatments

\begin{tabular}{|c|c|c|c|c|c|c|}
\hline \multirow[t]{2}{*}{ Factor } & \multirow[t]{2}{*}{ Grup } & \multirow[t]{2}{*}{$\mathrm{N}$} & \multicolumn{2}{|c|}{$\begin{array}{l}\% \text { reduction of bacterial } \\
\text { viability }\end{array}$} & \multicolumn{2}{|c|}{ ANOVA Factorial test } \\
\hline & & & average & SD & Sig & conclusion \\
\hline \multirow[t]{7}{*}{ Laser } & Laser $10 \mathrm{~s}^{(\mathrm{a})}$ & 4 & 42.74 & 5.49 & \multirow{7}{*}{$\begin{array}{c}\mathrm{p}= \\
0.000\end{array}$} & \multirow{7}{*}{$\begin{array}{l}\text { Significant } \\
\text { difference }\end{array}$} \\
\hline & Laser s $30 \mathrm{~s}{ }^{(\mathrm{ab})}$ & 4 & 44.91 & 1.69 & & \\
\hline & Laser $50 \mathrm{~s}^{(\mathrm{ab})}$ & 4 & 46.28 & 1.90 & & \\
\hline & Laser $70 \mathrm{~s}^{(\mathrm{ab})}$ & 4 & 48.37 & 4.28 & & \\
\hline & Laser $90 \mathrm{~s}{ }^{(\mathrm{abc})}$ & 4 & 69.33 & 3.61 & & \\
\hline & Laser $120 \mathrm{~s}^{(\mathrm{c})}$ & 4 & 88.50 & 2.83 & & \\
\hline & Total & 72 & 61.76 & 3.26 & & \\
\hline \multirow[t]{10}{*}{ Doxy $0.1 \%$} & Doxy $10 \mathrm{~s}^{(\mathrm{ab})}$ & 4 & 44.92 & 2.50 & \multirow{7}{*}{$\begin{array}{c}\mathrm{p}= \\
0.000\end{array}$} & \multirow{7}{*}{$\begin{array}{l}\text { Significant } \\
\text { difference }\end{array}$} \\
\hline & Doxy $30 \mathrm{~s}^{(\mathrm{ab})}$ & 4 & 49.05 & 3.95 & & \\
\hline & Doxy $50 \mathrm{~s}^{(\mathrm{ab})}$ & 4 & 50.61 & 3.97 & & \\
\hline & Doxy $70 \mathrm{~s}{ }^{(a b c)}$ & 4 & 57.08 & 3.05 & & \\
\hline & Doxy $90 \mathrm{~s}{ }^{(\mathrm{abc})}$ & 4 & 59.19 & 3.93 & & \\
\hline & Doxy $120 \mathrm{~s}^{(\mathrm{abc})}$ & 4 & 59.64 & 3.62 & & \\
\hline & Total & 72 & 61.76 & 3.26 & & \\
\hline & Laser+Doxy $10 \mathrm{~s}^{(\mathrm{abc})}$ & 4 & 58.30 & 3.05 & \multirow{3}{*}{$\begin{array}{c}p= \\
0.000\end{array}$} & \multirow[b]{3}{*}{ Significant } \\
\hline & Laser+Doxy $30 \mathrm{~s}^{(\mathrm{abc})}$ & 4 & 70.70 & 2.43 & & \\
\hline & Laser+Doxy $50 \mathrm{~s}^{(\mathrm{abc})}$ & 4 & 77.20 & 2.03 & & \\
\hline
\end{tabular}




\begin{tabular}{|c|c|c|c|c|c|c|}
\hline \multirow{4}{*}{$\begin{array}{l}\text { Laser } \\
0.1 \%\end{array}$} & \multirow[t]{4}{*}{ Doxy } & Laser+Doxy $70 \mathrm{~s}{ }^{(a b c)}$ & 4 & 77.60 & 2.82 & \multirow[t]{4}{*}{ difference } \\
\hline & & Laser+Doxy $90 \mathrm{~s}{ }^{(\mathrm{bc})}$ & 4 & 78.50 & 1.70 & \\
\hline & & Laser+Doxy $120 \mathrm{~s}^{\text {(c) }}$ & 4 & 88.79 & 2.60 & \\
\hline & & Total & 72 & 6176 & 1926 & \\
\hline
\end{tabular}

\section{Discussion}

Antibiotics such as doxycycline have been shown to inhibit several matrix metalloproteinases in addition to its antimicrobial activity (Hanem et al., 1998; Ryan et al., 1998; Chang et al., 2010). Doxycycline has disadvantage during treatment because it will be lead photosensitivity on UV-A or 350nm-400nm (Goetze et al., 2017). However, our result has the absorbance of doxycycline reach $410 \mathrm{~nm}$ before falling down. It will be an advantage when PDT is combined with the antibiotic. Doxycycline also is known to disrupt the function of mitochondria (Moullan et al., 2015) and produces oxygen species that play a role in the activation procollagenases and progelatinases in vitro (Ramamurthy et al., 1993, Smith et al, 1996). Doxycycline modulates other cellular functions, including proliferation and matrix remodeling (Franco et al., 2006). Our result on treatment provides group doxycycline treatment give decreased more than the control group. Topically administered of doxycycline $0,1 \%$ has been used for the treatment of periodontitis without adverse or side effects reaction. Doxycycline appears to be a promising photosensitizer in PDT. This study showed the possibility to kill A.actinomycetemcomitans in vitro by using topically applied doxycycline $0,1 \%$ combination with 408 $\mathrm{nm}$ diode laser. Doxycycline used at therapeutic concentrations do not have toxicity but after laser exposure, they show phototoxicity. This behavior is caused by their photodegradation products and their reactive nature. The mechanism of cellular damage is associated with an increase of oxidation in biomacromolecules such as albumin (BSA) and RNase A, the cellular damage via oxidation of specific aromatic amino acids. Photoaffinity of studied compounds for albumin and others proteins is related to the different lipophilic proprieties shown for the seven tetracyclines derivatives. Doxycycline is the most phototoxic compound of the series tetracycline (Fuoco, 2015)

Photodynamic therapy (PDT) utilizes visible light (laser) and dye (photosensitizer), which produce free oxygen radicals to selectively destroy bacteria and their by-products. PDT combines non-toxic photoactive dyes and harmless visible light to produce singlet oxygen and free radicals to kill microbial cells. The effectiveness of PDT as assessed by previous studies has been focusing on various microorganisms and photosensitizers. Studies of the susceptibility of A.actinomycetemcomitansto lethal photosensitization in vitro have reported that the organism can be killed with low concentrations of methylene blue and low light energy doses. Methylene blue caused 64\% bacterial reduction, therefore seen to be less efficient on A.actinomycetemcomitans (Lang et al., 2009). A more recent study using photosensitizers based on porphyrin skeleton and a red laser showed only $62 \%$ reduction of A.actinomycetemcomitans (Andriankaja et al., 2010).

In this study, doxycycline $0.1 \%$ has the effect of reducing the bacterial viability of $(59.60 \pm 3.26 \%)$. Whereas laser exposure $120 \mathrm{~s}$ combined with doxycycline produce the effect of bacterial viability reduction $(88.50 \pm 2.83 \%)$ is not significantly different from the effect of laser $120 \mathrm{~s}$ exposure $(88.79 \pm 2.60 \%)$. In clinical treatment, the application of laser exposure is generally at the duration of the exposure time of 30s. The results of this study indicate that the du-

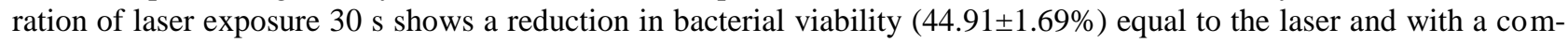
bination of doxycycline and laser exposure $(70.70 \pm 2.43 \%)$. So at low doses of laser exposure, doxycycline $0.1 \%$ combined with the laser results in the greatest reduction in bacterial viability, significantly different from laser exposure alone.

Photodynamic Inactivation (PDI) is a method for inactivation in microbes. The combination of light and certain photosensitizer in PDI will cause photoinactivation in bacteria (Wardle, 2009), ie inhibition of cell metabolic activity due to cytoplasmic membrane damage due to peroxidation by reactive oxygen (Hamblin \& Hasan, 2003). Photoinactivation mechanism involves the process of photosensitization, which is the process of light absorption by photosensitizer molecules which further activate the chemical reaction produces various species of reactive oxygen. Photosensitization depends on the type and quantity of photosensitizer acting as light-absorbing molecules (Nitzan et al., 2004) and the suitability of the light spectrum with the photosensitivity absorptive spectrum (Papageorgiou et al., 2000). At the molecular level due to irradiation begins with a photophysical event of light absorption which further activates photosensitizer molecules, followed by photochemical reactions that produce various species of reactive oxygen (Plaetzer et al., 2009). Reactive oxygen causes lipid peroxidation in cell, lysis or inactivation of membrane transport systems in these bacterial cells, and bacterial cell damage (Hamblin \& Hasan, 2003).

The success of photodynamic therapy depends on the suitability of the light source wavelength spectrum with the photosensitizer absorption spectrum. In this study the absorption spectrum of doxycycline at $408 \mathrm{~nm}$, while the laser light source used $409 \mathrm{~nm}$. So doxycycline as photosensitizer able to absorb (quantum yield) the laser light energy $99.99 \%$. Bacterial reduction differs depending on the quantum yield density of photosensitizer. To determine effective dose treatment of PDT is difficult because concentration photosensitizer and light absorption have certain measurement (Hegge et al., 2012). High light energy may be not enough to decreased bacteria caused quantum molecular process. The lower light energy doses used (6 and $12 \mathrm{~J}$ ), the extent of bacterial killing increased markedly as the photosensitizer concentration increased. The results imply that even at the lowest light energy dose used (6 J), enough photons were being supplied to activate all of the photosensitizer molecules present (resulting from the application of $0,1 \%$ of doxycycline to release sufficient ROS) to enable the killing of most (approximately 90\%) bacteria present. The killing 101 
of bacteria with the light energy dose was limited by the concentration of the photosensitizer at the site or, more strictly, its ROS-generating capacity.

Local antimicrobial agents should be applied in the treatment of periodontitis (Bernhart et al., 2016). However, it is difficult to maintain the level of therapeutic agents for a long time due to elution agent by the gingival crevicular fluid. To resolve this problem, fiber insertion, strip, and resorbable cellulose that release agent slowly into the periodontal pocket have been used (Kim et al., 2015). Biodistribution of topically applied doxycycline on the gingival structures showed penetration by photosensitizer throughout the epithelium. Following subsequent illumination, the photodynamic effect was limited to the epithelium. When the highest concentration was used, the most intense fluorescence throughout the epithelial layer is observed, but the intensity of fluorescence in the connective tissue is very low. Penetration throughout the epithelium and connective tissues may be important, as periodontopathogens can infiltrate through the epithelial barrier into the connective tissue (Marchetti et al., 2012). PDT can possibly eliminate bacteria that have migrated to the tissue. The use of PDT is not affected by such problem, since the photosensitizer administration into periodontal pocket only needs a short time; maybe minutes or even seconds, depending on light source intensity used (Gursoy et al., 2013)This study showed that $0.1 \%$ of doxycycline reduces the number of A.actinomycetemcomitans below detectable level within only $30 \mathrm{~s}$ exposure. Compared to conventional therapy, adjunctive therapy encompasses new technologies and office procedures such as light and laser therapy, photodynamic therapy. The demand for adjunctive therapy arises from the desire for more effective and quicker therapy.

\section{Conclusions}

In this study, doxycycline $0.1 \%$ has the effect of reducing the bacterial viability of $(59.60 \pm 3.26 \%)$. Whereas laser exposure $120 \mathrm{~s}$ combined with doxycycline produce the effect of bacterial viability reduction $(88.50 \pm 2.83 \%)$ is not significantly different from the effect of laser $120 \mathrm{~s}$ exposure $(88.79 \pm 2.60 \%)$. In clinical treatment, the application of laser exposure is generally at the duration of the exposure time of $30 \mathrm{~s}$. The results of this study indicate that the duration of laser exposure $30 \mathrm{~s}$ shows a reduction in bacterial viability $(44.91 \pm 1.69 \%)$ equal to the laser and with a combination of doxycycline and laser exposure $(70.70 \pm 2.43 \%)$. So at low doses of laser exposure, doxycycline $0.1 \%$ combined with the laser results in the greatest reduction in bacterial viability, significantly different from laser exposure alone.

Conflict of Interest: The authors report no conflict of interest and the article is not funded or supported by any research grant.

\section{References}

1. Andriankaja OM, Sreenivasa S, Dunford R, DeNardin E. (2010). Association between metabolic syndrome and periodontal disease. Aust Dent J; 55:252-259. doi:10.1111/j.1834-7819.2010.01231.x

2. Bernhart T, Mailath-pokorny G. (2016) Lethal photosensitization for decontamination of implant surfaces in the treatment of peri-implantitis Lethal photosensitization for decontamination of implant surfaces in the treatment of periimplantitis. 2016; doi:10.1034/j.1600-0501.2001.012002104.x.

3. Brayton JJ, Yang Qing Y, Nakkula Robin J, MS1 and WJDW. (2002). An in vitro model of ciprofloxacin and minocycline transport by oral epithelial cells.; 73(11):1267-1272.

4. Chang WY, Clements D, Johnson SR. (2010). Effect of doxycycline on proliferation, MMP production, and adhesion in LAM-related cells. Am J Physiol Lung Cell Mol Physiol.; 299(3):L393-400. doi:10.1152/ajplung.00437.2009.

5. Choi K-H, Lee H-J, Park BJ, Wang K.K., Shin E.P., Park J.C., Kim Y.K., Oh M.K. and Kim Y.R. (2012). Photosensitizer and vancomycin-conjugated novel multifunctional magnetic particles as photoinactivation agents for selective killing of pathogenic bacteria. Chem Commun (Camb).; 48(38):4591-4593. doi:10.1039/c2cc17766h.

6. Curtis MA, Zenobia C, Darveau RP. (2011). The Relationship of the Oral Microbiotia to Periodontal Health and Disease. Cell Host Microbe.; 10(4):302-306. doi:10.1016/j.chom.2011.09.008.

7. De Melo WC, Avci P, de Oliveria MN, Gupta A., Vecchio D., Sadasivam M., Chandran R., Huang YY., Yin R., Perussi L.R., Tegos G.P., Perussi J.R., Dai T. and Hamblin M.R (2013). Photodynamic inactivation of biofilm: taking a lightly colored approach to stubborn infection. Expert Rev Anti Infect Ther.; 11(7):669-693. doi:10.1038/nature13314.A.

8. Franco C, Ho B, Mulholland D, Hou G., Islam M., Donalson K. and Bendeck M.P. (2006) Doxycycline Alters Vascular Smooth Muscle Cell Adhesion, Migration, and Reorganization of Fibrillar Collagen Matrices. Am J Pathol.; 168(5):1697-1709. doi:10.2353/ajpath.2006.050613.

9. Fuoco D (2015) Cytotoxicity Induced by Tetracyclines via Protein Photooxidation Advances in Toxicology. Hindawi Publishing Corporation. http://dx.doi.org/10.1155/2015/787129

10. Goetze, S., Hiernickel, C., and Elsner, P. (2017). Phototoxicity of Doxycycline: A Systematic Review on Clinical Manifestations, Frequency, Cofactors, and Prevention. Ski. Pharmacol Physiol 30: 76-80.

11. Gursoy H, Ozcakir-Tomruk C, Tanalp J, Yilmaz S. (2013). Photodynamic therapy indentistry: A literature review. Clin Oral Investig.; 17(4):1113-1125. doi:10.1007/s00784-012-0845-7.

12. Hanemaaijer R, Visser H, Koolwijk P, Sorsa T, Salo T., Golub L.M. and Van Hinsbergh V.W.M. (1998). Inhibition of MMP Synthesis by Doxycycline and Chemically Modified Tetracyclines (CMTs) in Human Endothelial Cells. Adv Dent Res.;12(1):114-118. doi:10.1177/08959374980120010301. 
13. Hamblin, M.R., Hasan, T., (2003). Photodynamic Therapy: a New Antimicrobial Approach to Infectious Disease?, Journal of Photochem and Photobio B: Biology, Science, 3,436-450

14. Hegge, A.B., Bruzell, E., Kristensen, S., and Tonnesen, H.H. (2012). Photoinactivation of Staphylococcus epidermidis biofilms and suspensions by the hydrophobic photosensitizer curcumin - Effect of selected nanocarrier: Studies on curcumin and curcuminoides XLVII. Eur. J. Pharm. Sci. 47: 65-74.

15. Kim J, Kim S, Choi H, Kim O. (2015). Effects of the antimicrobial peptide cathelicidin (LL-37) on immortalized gingival fibroblasts infected with Porphyromonas gingivalis and irradiated with 625-nm LED light.; 30(8):2049-2057

16. Lai PC, Walters JD. (2013). Azithromycin kills invasive aggregatibacter actinomycetemcomitans in gingival epithelial cells. Antimicrob Agents Chemother.; 57(3):1347-1351. doi:10.1128/A.ACTINOMYCETEMCOMITANSC.02558-12.

17. Lang NP, Schätzle MA, Löe H. (2009). Gingivitis as a risk factor in periodontal disease. J Clin Periodontol.; 36(10):38. doi:10.1111/j.1600-051X.2009.01415.x.

18. Marchetti E, Monaco A, Procaccini L, Mummolo S., Gatto R., Tete S., Baldini A. , Tecco S. and Marzo G. (2012). Periodontal disease: the influence of metabolic syndrome. Nutr Metab (Lond).; 9(1):88. doi:10.1186/1743-7075-9-88.

19. Moslemi N, Heidari M, Bouraima SA. (2012). Antimicrobial Photodynamic Therapy as an Adjunctive Modality in the Treatment of Chronic Periodontitis.; Journal of Lasers in Med. Sci. 3(4):141-146.

20. Moullan N, Mouchiroud L, Wang X, Ryu D., William E.G., Mottis A., Jovaisaite V., Frochaux M.V., Quiros P.M., Deplancke B., Houtkooper R.H. and Auwerx J. (2015). Tetracyclines disturb mitochondrial function across eukaryotic models: A call for caution in biomedical research. Cell Rep.; 10(10):1681-1691. doi:10.1016/j.celrep.2015.02.034

21. Nitzan Y., Divon M.S., Shporen E., Malik Z., (2004). ALA Induced Photodynamic Effect on Gram Positive and Negative Bacteria, Journal of Photochemistry and Photobiology P: Physics., 3: 430-435

22. Papageorgiou, Katsambas A., Chu A. (2000). Phototherapy with Blue (415nm) and Red (660nm) Light in The Treatment of Acne Vulgaris, British Journal of Dermatology 142:973-978

23. Peacock, D.L., Frcp, C., Wong, L.T.K., Frcp, C., Davidson, A.G.F., and Frcp, C. (2000). An Unusual Presentation of Doxycycline-Induced Photosensitivity. Pediatrics 106.

24. Plaetzer K., Krammer B., Berlanda J., Berr F. (2009). Photophysics and Photochemistry of Photodynamic Therapy: Fundamental Aspects, Journal of Laser Medical Sciences, 24: 259-268

25. Ramamurthy NS, Vernillo A.T., Greenwald R.A., Lee H.M., Sorsa T., Golub L.M and Rifkin B.R (1993). Reactive oxygen species activate and tetracyclines inhibit rat osteoblast collagenase. J Bone Miner Res.; 8(10):1247-1253. doi:10.1002/jbmr.5650081013.

26. Ryan ME, Ashley RA. (1998). How do tetracyclines work? Adv Dent Res.; 12(2):149-151. doi:10.1177/08959374980120011101.

27. Séguier S, Souza SLS, Sverzut AC V, Simioni A.R., Primo F.L., Bodineau A., Correa V.M.A, Coulomb B. and Tedesco A.T. (2010). Impact of photodynamic therapy on inflammatory cells during human chronic periodontitis. $J$ Photochem Photobiol B Biol.; 101(3):348-354. doi:10.1016/j.jphotobiol.2010.08.007.

28. Setiawatie EM, Astuti SD, Zaidan AH. (2016). An in vitro Anti-microbial Photodynamic Therapy (aPDT) with Blue LEDs to Activate Chlorophylls of Alfalfa Medicago sativa L on Aggregatibacter actinomycetemcomitans. J Int Dent Med Res.; 9(2):118-125.

29. Sgolastra F, Petrucci A, Gatto R, Marzo G, Monaco A. (2013). Photodynamic therapy in the treatment of chronic periodontitis: A systematic review and meta-analysis. Lasers Med Sci.; 28(2):669-682. doi:10.1007/s10103-011-10022 .

30. Smith GN, Brandt KD, Hasty KA. (1996). Activation of recombinant human neutrophil procollagenase in the presence of doxycycline results in fragmentation of the enzyme and loss of enzyme activity. Arthritis Rheum.;39(2):235-244. doi:10.1002/art.1780390209. 